\title{
Effects of home environment and center-based child care quality on children's language, communication, and literacy outcomes ${ }^{\text {is }}$
}

\author{
Ana Isabel Pinto ${ }^{\mathrm{a}, *}$, Manuela Pessanha ${ }^{\mathrm{b}}$, Cecília Aguiarc $^{\mathrm{c}, 1}$ \\ a University of Porto, Department of Psychology, Portugal \\ b Polytechnic Institute of Porto, College of Education, Portugal \\ c UIPCDE, ISPA - University Institute, Portugal
}

\section{A R T I C L E I N F O}

\section{Article history:}

Received 2 August 2011

Received in revised form 17 June 2012

Accepted 1 July 2012

\section{Keywords:}

Child care quality

Home environment quality

Language and communication development

Early literacy

\begin{abstract}
A B S T R A C T
This study examined the joint effects of home environment and center-based child care quality on children's language, communication, and early literacy development, while also considering prior developmental level. Participants were 95 children ( 46 boys), assessed as toddlers (mean age $=26.33$ months; Time 1 ) and preschoolers (mean age $=68.71$ months; Time 2 ) and their families. At both times, children attended center-based child care classrooms in the metropolitan area of Porto, Portugal. Results from hierarchical linear models indicated that home environment and preschool quality, but not center-based toddler child care quality, were associated with children's language and literacy outcomes at Time 2 . Moreover, the quality of preschool classrooms moderated the association between home environment quality and children's language and early literacy skills - but not communication skills - at Time 2, suggesting the positive cumulative effects of home environment and preschool quality. Findings further support the existence of a detrimental effect of low preschool quality on children's language and early literacy outcomes: positive associations among home environment quality and children's developmental outcomes were found to reduce substantially when children attended low-quality preschool classrooms.
\end{abstract}

\section{Effects of home environment and center-based child care quality on children's language, communication, and literacy outcomes}

The demand for early childhood education and care (ECEC) outside the family context in Portugal has grown in response to the increase in the proportion of working mothers. Portugal has the highest rate of mothers working full time in the European Union. In $2005,69.1 \%$ of mothers with children under 2 years and $71.8 \%$ of mothers with children between 3 and 5 were employed (Organization for Economic Co-operation and Development [OECD], 2007).

Over the past two decades, substantial efforts have been made by the Portuguese government to increase the coverage rate of ECEC services. Sociopolitical changes that occurred in Portugal, mainly following the 1974 revolution, increased women's access to

\footnotetext{
is This work was funded by FCT - Fundação para a Ciência e a Tecnologia, through research grants "POCTI/PSI/35207/1999" and "POCI/PSI/58712/2004".

* Corresponding author at: Faculdade de Psicologia e de Ciências da Educação da Universidade do Porto, Rua Alfredo Allen, 4200-135 Porto, Portugal. Tel.: +351 226079748 .

E-mail address: ana@fpce.up.pt (A.I. Pinto).

1 Now at ISCTE - University Institute of Lisbon.
}

labor and restarted the debate on ECEC. In 1975, a report from the United Nations Educational, Scientific, and Cultural Organization (UNESCO), highlighted the precarious state of preschool services in Portugal and stated the need to create 12,000 new classrooms for ECEC (UNESCO, 1982). This report influenced the adoption of a public law recommending the implementation of a network of public preschool services (Bairrão, Leal, Abreu-Lima, \& Morgado, 1997; Vasconcelos, Orey, Homem, \& Cabral, 2002). Until 1981, official data on infant-toddler child care and preschool services in Portugal were scarce and unreliable. In the last two decades, the coverage rate for children between 4 months and 3 years of age has increased drastically from $5.8 \%$ in 1984 (Vasconcelos et al., 2002) to $30.2 \%$ in 2008 (Gabinete de Estratégia e Planeamento, 2009). In the mainland, the coverage rate of educational services for children between 3 and 6 years has increased from 32\% in 1984 (Vasconcelos et al., 2002) to $78.8 \%$ in 2008 (Ministério da Educação, 2010). However, statefunded early educational services are still insufficient (Conselho Nacional de Educação, 2011).

As previously mentioned in a Portuguese study by Pessanha, Aguiar, and Bairrão (2007), ECEC services for children between 4 months and 3 years of age are all dependent on the Ministry of Solidarity and Social Security and are set up either by the Ministry itself or by other private entities (e.g., individuals, cooperatives, or non-profit organizations) (Bairrão, Barbosa, Borges, Cruz, 
\& Macedo-Pinto, 1990; Vasconcelos et al., 2002). Regarding ECEC services for children from 3 to 6 years of age, public and private preschool services form a national network under the responsibility of the Ministry of Education, whose aim is to extend preschool education provision to all children of this age group (Bairrão et al. 1990; Ministério da Educação, 2000).

In recent years, Portugal has made notable progress in the formulation and implementation of ECEC policy with increased enrollment rates, the expansion of publicly funded preschool programs, and recognition of the critical role of early educational experiences. According to the OECD, almost $90 \%$ of children aged 5-6 years were enrolled in ECEC in 2006. More recently, the central government has mandated universal preschool for 5-year-olds (Ministério da Educação, 2009).

Considering the research findings on the compensatory effects of high-quality ECEC for disadvantaged children (see PeisnerFeinberg \& Yazejian, 2010), it can be argued that the quality of preschool contexts is of crucial relevance in Portugal, where the risk of poverty is around $17.9 \%$ for the overall population and over $20.6 \%$ for families with children (Instituto Nacional de Estatística, 2010). Moreover, maternal education is low when compared to other European Union countries, with $70 \%$ of mothers having completed less than upper secondary education (OECD, 2008).

Over the past decades, the increase in the number of infants, toddlers, and preschoolers receiving ECEC has generated an abundance of research on the effects of early child care experiences on children's developmental outcomes. A considerable number of studies have demonstrated the short and long-term effects of developmentally appropriate, high-quality ECEC on children's cognitive, language, and social outcomes as well as on later school achievement (Burchinal, Roberts, Nabors, \& Bryant, 1996; Burchinal, Peisner-Feinberg, Pianta, \& Howes, 2002; Howes et al., 2008; Mashburn et al., 2008; Pessanha, 2008; Vandell, Belsky, Burchinal, Steinberg, \& Vandergrift, 2010). For example, the largescale National Institute on Child Health and Human Development [NICHD] child care study (1997, 1998a, 1998b, 2000, 2006) investigated the interactions between child, home environment, and ECEC characteristics to help explain how children developed over time. The results were generally consistent with findings from other studies and demonstrate that the quality of both the home and ECEC environments matter. When care environments were more stimulating and well organized, children had better vocabulary, more advanced attention and memory skills, and peer relationships. Furthermore, in the preschool years, children who spent more hours in center-based child care displayed more advanced language and cognitive skills.

Given previous findings on the positive effects of preschool experience on primary school performance (see Sammons et al., 2002, 2003), the first major European longitudinal study - Effective Provision of Pre-School Education (EPPE; Sylva, Melhuish, Sammons, Siraj-Blatchford, \& Taggart, 2008) - was conducted to analyze the long-term influence of preschool on children's performance in school. EPPE measured preschool quality using the Early Childhood Environment Rating Scale-Revised (ECERS-R; Harms, Clifford, \& Cryer, 1998) and the Early Childhood Environment Rating Scale-Extension (ECERS-E; Sylva, Siraj-Blatchford, \& Taggart, 2003) with a sample of 3-7year old children. The study identified a relationship between high-quality preschool and higher intellectual and social/behavioral development in children, with subsequent positive outcomes in mathematics and reading. However, despite earlier findings suggesting that all preschool experience was beneficial, EPPE participants who attended lowquality preschool did not show cognitive benefits in primary school, and their outcomes did not significantly differ from the children who did not attend preschool (Sylva et al., 2008).
According to Ahnert and Lamb (2004), cognitive theorists have maintained a more positive view of ECEC, emphasizing the positive impact of well-planned learning environments on the cognitive and communicative development of children. However, these authors underline that, rather than considering child care effects as universal, the influence of several factors (e.g., cultural, family, and child characteristics) should be taken into account when analyzing the association between the quality of early childhood environments and children's development.

Although there is a great deal of evidence suggesting that ECEC can have a long-lasting influence on child outcomes, the home environment is widely recognized as the most important influence on children's adjustment (e.g., NICHD, 1998b), with family characteristics such as maternal education consistently emerging as strong predictors of children's academic and cognitive outcomes (e.g., Abreu-Lima, Leal, Cadima, \& Gamelas, 2012). However, the quality of the home learning environment has been found to be more important for children's intellectual and social development than parental occupation, education, or income (Sylva et al., 2008).

While single factors have been looked at in a number of studies, evidence regarding the interaction effects of home and ECEC quality on children's outcomes is scarce and the inconsistency of what is available suggests the need for additional research. For example, in the NICHD child care study (1997, 1998a, 1998b, 2000, 2006), significant interaction effects between quality of home environment and ECEC quality were found, indicating that children were less likely to be secure when low maternal sensitivity/responsiveness was combined with poor-quality child care. Further, Watamura, Phillips, Morrissey, McCartney, and Bub (2011) found cross-context influences on children's social-emotional outcomes, reporting both detrimental effects of double jeopardy (i.e., low-quality home and ECEC environments) and compensatory effects of attending highquality ECEC for children from lower-quality home environments. Bradley, McKelvey, and Whiteside-Mansell (2011) reported a predominance of additive effects of the home environment and ECEC. However, the authors found small moderating effects of home environment features on the impact of ECEC, with ECEC sometimes compensating for low levels of stimulation and warmth in the home environment, but rarely potentiating the effects of high-quality home environments. With a focus on early literacy skills, Anders et al. (2011) found that children from mediumquality home environments benefited from attending high-quality preschool whereas children from low-quality home environments did not. The authors acknowledge a diverse pattern of results, possibly specific to Germany. However, this furthers the argument for continued research on the interplay of home and ECEC experiences across diverse samples.

This study aims to help fill this gap by analyzing both the direct and joint effects of home environment and ECEC quality in a Portuguese sample. Considering the low quality of Portuguese toddler center-based child care, reported in previous studies (Barros \& Aguiar, 2010; Pessanha et al., 2007), as well as the specific cultural background of the present study's participants, results may provide additive value to understanding the complicated and contextual nature of young children's early care and education experiences.

This paper is based on a data set from the first two data points of a longitudinal study on young children's engagement. In the first phase of the study, predictors of child engagement and development were identified in 1-3 year-olds, namely setting characteristics (i.e., home environment and center-based toddler child care), adult's interactive behaviors, and child characteristics. In the second phase of the study, a follow-up of these children at ages 4-6years was carried out in order to analyze the influence of engagement, as observed in toddler child care classrooms, on children's later adaptation. Both data points included a considerable number of measures, with similar instruments utilized for 
measuring primary variables. For example, at both data points, child engagement was coded using the Portuguese translation of the Engagement Quality Observation System (McWilliam \& de Kruif, 1998; Pinto, Aguiar, Barros, \& Cruz, 2004); child development was measured using the Portuguese adaptation of the Griffiths Mental Development Scales (Griffiths, 1984/1996, 1986/1996); child adaptive behavior was measured using the Portuguese translation and adaptation of the age-appropriate survey form of the Adaptive Behavior Scales (Sparrow, Balla, \& Cicchetti, 1984/n.d.); home environment quality was measured with the Portuguese translation of the age-appropriate version of the Home Observation for Measurement of the Environment (HOME; Caldwell \& Bradley, 1984/1997); and center-based classroom quality was measured using the Portuguese version of the Infant Toddler Environment Rating Scale (ITERS; Harms, Cryer, \& Clifford, 1990/1996), in the first data point, and the Portuguese version of the ECERS-R (Harms et al., 1998/2008) in the second. Similar psychometric properties were found for these measures at both times (see the methods section for a more detailed description). Results from the first phase of this study showed that homogeneously low toddler child care classroom quality was associated with time children spent nonengaged as well as with lower percentages of toddlers engaged in activities (Pinto, 2006). In addition, higher toddler child care classroom quality was associated with children's communication competence and home quality was moderately associated with different developmental areas (i.e., cognitive, social, and communication skills) (Pessanha, 2008).

Building on the literature mentioned above, we examined associations between children's language, communication, and literacy skills during preschool and (a) the overall quality of centerbased toddler child care, (b) the overall quality of the preschool environment, and (c) the overall home environment quality. All associations were examined while also considering children's prior developmental level as well as maternal education. Our hypotheses were the following:

1. The overall quality of center-based toddler child care is positively associated with children's language, communication, and early literacy skills during preschool.

2. The overall home environment quality is positively associated with children's language, communication, and early literacy skills during preschool.

3. The overall quality of the preschool environment is positively associated with children's language, communication, and early literacy skills during preschool, when also considering home environment quality, maternal education, and children's previous developmental level.

4. The overall quality of the preschool environment has a moderating effect on the relationship between home environment quality and children's language, communication, and early literacy skills during preschool, when also considering maternal education and children's previous developmental level. It is expected that higher preschool quality potentiates the positive effects of home quality.

Results may provide evidence for the need to improve the quality of ECEC experiences. This is especially important in Portugal, where publicly supported ECEC is a fast growing sector.

\section{Methods}

\subsection{Participants}

The data used in this study was drawn from a longitudinal study on child engagement. Participants included 95 children (46 boys) and their families living in the metropolitan area of Porto. To provide some context, Porto is the second largest metropolitan area in Portugal, with approximately 1,500,000 inhabitants (Área Metropolitana do Porto, n.d.). From the initial sample of 120 typically developing children (60 boys), we retained participants for whom two data points were available: one data point during the toddler years (Time 1 ) and one data point during the preschool period (Time 2). Procedures for the initial sample were previously described by Pessanha et al. (2007): 15 private infant-toddler child care centers were randomly selected, followed by random selection of 4 children ( 2 boys and 2 girls) in each of the 30 participating toddler child care classrooms.

At Time 1 , children were $14-40$ months $(M=26.33, S D=6.51)$. Mothers' age averaged 31.21 years $(S D=4.77)$, 84\% were married, and $91 \%$ worked outside their home. Maternal education ranged from 3 to 18 years $(M=10.64, S D=4.47)$, with $29 \%$ of the mothers having completed a college degree. Family income averaged $1,388.63$ Euros per month $(S D=735.20)$. Children attended 15 classrooms for 1-year-olds and 15 classrooms for 2-year-olds (from 11 private non-profit centers and 4 private for-profit centers). In these toddler classrooms mean group size was $16.00(S D=5.07)$ and mean adult-child ratio was $1: 8(S D=1: 3)$.

At Time 2, children's age averaged 68.71 months $(S D=5.91)$ and family income averaged 1574.29 Euros per month $(S D=801.67)$. Children attended 41 preschool classrooms from 29 centers ( 13 private non-profit, 6 private for-profit, 5 public, and 5 with no center type information available) in the same geographic area. In these preschool classrooms mean group size was $22.50(S D=4.23)$ and mean adult-child ratio was $1: 13(S D=1: 4)$.

In this study, at Time 1, the number of target-children in each of the toddler classrooms ranged between 2 and $4(M=3.17, S D=0.79)$. At Time 2, the number of target-children per preschool classroom ranged between 1 and $7(M=2.32, S D=1.47)$.

\subsection{Measures and procedures}

\subsubsection{Child outcomes}

To measure children's global development, both at Times 1 and 2, we used a Portuguese adaptation of the Griffiths Mental Development Scales (Griffiths, 1984/1996, 1986/1996). This measure covers birth to 8 years of age and includes a total of 468 items across six subscales or developmental domains: locomotor (i.e., gross motor skills), personal-social (i.e., independence and interaction), hearing and speech, eye and hand coordination (i.e., fine motor skills), performance, and practical reasoning. Raw scores may be adjusted for children's chronological age and converted into a developmental quotient. The Portuguese version used in this study has been used in previous research (Cordazzo, Almeida, \& Vieira, 2011; Pereira et al., 2010). In this study, Cronbach's alpha for the global scale was .98 at Time 1 and .97 at Time 2. We also used the developmental quotient of the Hearing and Speech subscale, as collected at Time $2(\alpha=.84)$, as a measure of children's receptive and expressive language outcomes. The Griffiths scales were administered at each child's center by research assistants with a Psychology degree.The Portuguese translation and adaptation of the survey form of the Vineland Adaptive Behavior Scales (Sparrow et al., 1984/n.d.) was used to measure children's daily functioning. Although data were collected on the communication, daily living skills, and socialization domains at both Times 1 and 2, as required by our hypotheses, only data on communication skills for Time 2 are presented here. The communication scale used in this study included 10 items, rated on a 3 -point scale ( 0 , never performs behavior; 1 , sometimes or partially performs behavior; 2 , usually performs behavior). The questionnaire was filled out by preschool teachers and resulting scores on children's communication skills were internally consistent $(\alpha=.83)$. 
Finally, a Portuguese version of the Concepts About Print task (Clay, 2000/2003) was used, at Time 2, for measuring children's knowledge about the conventions and characteristics of written language and early literacy skills. This measure includes 23 dichotomous items, scored as 1 (correct) or 0 (incorrect) (Alves, Aguiar, Castro, \& Bairrão, 2004). While reading a specially designed children's book with child participants, researchers are able to assess children's knowledge of concepts such as title, front and back cover, beginning and direction of text, letter, word, etc. Previous studies have used the Portuguese version of this measure, reporting appropriate score reliability and validity (e.g., Cadima, Leal, \& Burchinal, 2010). For this study, a global score reflecting the number of concepts known to children was used $(\alpha=.85)$. This measure was administered in a quiet room at each child's center.

\subsubsection{Classroom quality}

To measure the overall quality of toddler child care classrooms at Time 1, we used a Portuguese translation of the ITERS (Harms et al., 1990/1996). The ITERS consists of 35 items, organized in seven subscales corresponding to areas of classroom quality: furnishings and display for children, personal care routines, listening and talking, learning activities, interaction, program structure, and adult needs. Each item is rated as a 7-point scale, with descriptors for 1 (inadequate), 3 (minimal), 5 (good), and 7 (excellent). Translation, training, and data collection procedures for this measure are available from Pessanha et al. (2007). In this study, Cronbach's alpha for the ITERS overall score, computed as the mean score across 33 items (2 items were removed due to lack of variance: item 31 - provisions for exceptional children - and item 23), was .80 .

The Portuguese translation of the ECERS-R (Harms et al., $1998 / 2008$ ) was used to measure preschool classrooms' overall quality at Time 2 . The ECERS-R consists of 43 items, organized in seven subscales that measure classroom space and furnishing, personal care routines, language and reasoning, activities, interaction, program structure, and parents and staff. As in ITERS, each item is presented as a 7-point scale, with descriptors for 1 (inadequate), 3 (minimal), 5 (good), and 7 (excellent). Data presented here are based on information collected over two mornings, which corresponds to $6 \mathrm{~h}$ of observation on average. Mean percentage of within-one agreement between raters was $87.7 \%(S D=9.91)$ and mean weighted Kappa coefficient was $.70(S D=.20)$. In this study, Cronbach's alpha for the ECERS-R overall score, computed as the mean score across all items, was .95 .

\subsubsection{Home environment quality}

To measure the quality of children's home environment at Time 1, we used the Portuguese translation of the Home Observation for Measurement of the Environment - Inventory for Families of Infants and Toddlers (HOME; Caldwell \& Bradley, 1984/1997). This measure is composed of 45 dichotomous items ( 1 , yes; 0 , no), organized in six subscales that measure parental emotional and verbal responsiveness, acceptance of the child's behavior, organization of the physical and temporal environment, provision of appropriate play materials, parental involvement with the child, and opportunities for variety in daily stimulation. Research assistants with a degree in Psychology visited children's families in their homes and conducted a semi-structured interview with mothers. In this study, we used an overall score computed as the sum of scores across all items. Cronbach's alpha for this overall score was .90.

\subsubsection{Demographic and structure information}

To collect data on parental and family characteristics at both time points, we used the Family Questionnaire developed by the European Child Care and Education (ECCE) Study Group (1997a). This questionnaire was administered during the home visits previously described. In addition, at both Times 1 and 2, the preschool and daycare structural characteristics questionnaire - interview with the classroom teacher (ECCE Study Group, 1997b) was used to collect data on teacher and classroom characteristics. Maternal education was considered an indicator of the child's socioeconomic status (SES). The decision to include this variable in the analysis was based on results of previous studies which suggest that maternal education provides a more reliable index of SES than family income or occupation prestige (Kagan, Lapidus, \& Moore, 1978; Roberts, Bornstein, Slater, \& Barrett, 1999).

\subsection{Data analyses}

Initial data analysis included examination of the reliability of scores, computation of descriptive statistics for all variables, and computation of correlation coefficients among variables of interest. In order to address aggregation bias and to account for children's mobility across ECEC settings, models for cross-classified random effects were tested, using hierarchical linear model (HLM; Raudenbush \& Bryk, 2002), to estimate components of variance in outcomes that lie between toddler child care classrooms, preschool classrooms, and children.

As specified in our hypotheses, criterion variables were children's language, children's communication skills, and children's knowledge of early literacy concepts. Results of the three-level HLM empty models for each criterion variable showed that two-level HLM models were appropriate for our study purposes. The HLM models included three variables at the child level (developmental level at Time 1, maternal education, and home environment quality) and one variable, preschool quality (ECERS-R global score at Time 2), at level 2 . All variables in the analyses were continuous and centered at the grand mean. The effect size for the main effect of both level-1 and level-2 predictors was computed as $B_{x} S D_{x} / S D_{y}$. According to the equation, the effect size was obtained by multiplying the unstandardized regression coefficient by the standard deviation for the predictor and then dividing by the standard deviation for the outcome (Morrison, Gutman, Sameroff, \& Cole, 2003; NICHD Early Child Care Research Network \& Duncan, 2003).

Moderation analyses tested whether the direction or strength of the relationship between home environment quality and child outcomes varied depending on preschool classroom quality. According to Baron and Kenny (1986), the moderator hypothesis is supported if the interaction between the predictor variable and the moderator is statistically significant. After testing for statistical significance, the effect sizes for these interactions were computed by estimating the coefficient for home environment quality when preschool classroom quality was $1 S D$ above and $1 S D$ below the mean (Morrison et al., 2003; NICHD Early Child Care Research Network \& Duncan, 2003). Effect sizes indicate the degree to which changes in standard deviation units in the predictor correspond to linear changes of one standard deviation in the outcome, such that -1 indicates a strong negative association, 0 indicates no association and 1 indicates a strong positive association. Since all predictors were continuous variables and the study was nonexperimental, .10 was considered a small effect size, .30 a moderate effect size, and .50 a large effect size (Cohen, 1988; NICHD, 2006). The database used in this study did not include missing values.

\section{Results}

Table 1 presents descriptive statistics on the child, home, and classroom variables involved in the analyses. Global quality of center-based toddler child care classrooms as measured by the ITERS was homogeneously low - as previously reported by Aguiar and McWilliam (2012) and Pessanha et al. (2007) - and average preschool quality as measured by the ECERS-R was slightly below 
Table 1

Descriptive statistics.

\begin{tabular}{|c|c|c|c|c|c|}
\hline & Scale & $N$ & $M$ & $S D$ & Range \\
\hline Toddler child care quality & $1-7$ & 30 & 2.55 & 0.42 & $1.76-3.47$ \\
\hline Preschool quality & $1-7$ & 41 & 3.32 & 0.89 & $2.01-6.09$ \\
\hline Maternal education (years) & & 95 & 10.64 & 4.47 & $3-18$ \\
\hline Time 1 home environment quality & $0-45$ & 95 & 35.48 & 7.22 & $17-45$ \\
\hline Time 1 developmental level & & 95 & 103.83 & 9.95 & $84.21-132.35$ \\
\hline Time 2 language: hearing and speech & & 95 & 93.04 & 12.62 & $63.80-131.40$ \\
\hline Time 2 communication & $0-30$ & 95 & 15.32 & 4.21 & $1-25$ \\
\hline Time 2 early literacy: concepts about print & $0-23$ & 95 & 7.44 & 4.30 & $1-22$ \\
\hline
\end{tabular}

Table 2

Bivariate correlations between children's developmental outcomes and home and child care quality.

\begin{tabular}{|c|c|c|c|c|c|c|c|}
\hline & 1 & 2 & 3 & 4 & 5 & 6 & 7 \\
\hline \multicolumn{8}{|l|}{ Child developmental outcomes } \\
\hline 1. Time 1 developmental level & - & & & & & & \\
\hline 2. Time 2 language: hearing and speech & .06 & - & & & & & \\
\hline 3. Time 2 communication & $.38^{*}$ & $.43^{*}$ & - & & & & \\
\hline 4. Time 2 early literacy: concepts about print & $.21^{*}$ & $.48^{*}$ & $.36^{*}$ & - & & & \\
\hline \multicolumn{8}{|l|}{ Home and child care quality } \\
\hline 5. Toddler child care quality & .08 & .08 & .01 & .06 & - & & \\
\hline 6. Preschool quality & $-.34^{*}$ & $.20^{*}$ & .07 & .13 & $.21^{*}$ & - & \\
\hline 7. Time 1 home environment quality & $.40^{*}$ & .17 & .18 & $.37^{*}$ & -.03 & -.07 & \\
\hline 8. Maternal education (years) & $.39^{*}$ & .18 & .17 & $.23^{*}$ & -.05 & -.14 & $.61^{*}$ \\
\hline
\end{tabular}

${ }^{*} p<.05$.

the scale's midpoint. None of the toddler child care classrooms and only $8 \%$ of preschool classrooms were in the good to excellent range. Although the mean home environment quality was relatively high, it showed a large variability among participants.

Table 2 presents a matrix displaying bivariate correlations between children's developmental level, children's language, communication, and early literacy skills, home environment quality, maternal education, overall quality of center-based toddler child care classrooms, and preschool quality. Some correlations were significantly different from zero. Supporting our hypothesis, positive statistically significant correlations were found between preschool quality and children's language as well as between home quality and children's early literacy skills.

Three-level HLM empty models examined components of variance at the child level (level 1), between toddler child care classrooms (level 2), and between preschool classrooms (level 3). Examination of results of these three-level HLM empty models for each criterion variable showed that there was no significant variability to be explained among toddler child care classrooms at Time 1, whereas there was significant between-group variance in preschool classrooms at Time 2. Based on these results, two-level HLM models were used to analyze the effects of preschool quality and home quality on child outcomes, when also considering child developmental level and maternal education at Time 1 . The between-group predictor at Time 1 , toddler child care classroom quality, as measured by the ITERS, was not considered for further analyses.

Results for the two-level HLM models (see Table 3) showed that, when also considering children's prior developmental level and maternal education, home environment quality at Time 1, was associated with children's language and early literacy skills at Time 2. Further, when accounting for both child and family variables, preschool quality was associated with children's concurrent early literacy skills. No direct effects of maternal education were found. In addition, there was a moderating effect of preschool quality in the association between home environment quality and two child outcomes: language and early literacy skills. The interpretation of this moderating effect indicates a synergetic positive effect in which the influence of home quality is stronger when preschool quality is higher. Specifically, when preschool quality is one standard

Table 3

Main and moderated fixed effects of home and preschool quality on children's developmental outcomes at Time 2.

\begin{tabular}{|c|c|c|c|c|c|c|c|c|c|}
\hline & \multicolumn{3}{|c|}{ Language: hearing and speech } & \multicolumn{3}{|c|}{ Communication } & \multicolumn{3}{|c|}{ Early literacy: concepts about print } \\
\hline & & $B($ se $)$ & Effect size & & $B($ se $)$ & Effect size & & $B($ se $)$ & Effect size \\
\hline Intercept & & \multicolumn{2}{|l|}{$92.87^{*}(1.57)$} & & \multicolumn{2}{|l|}{$15.05^{*}(0.49)$} & & \multicolumn{2}{|l|}{$7.66^{*}(0.47)$} \\
\hline \multicolumn{10}{|l|}{ Main effects } \\
\hline \multicolumn{10}{|l|}{ Level 1} \\
\hline Time 1 developmental & & $0.16(0.11)$ & .13 & & $0.21^{*}(0.04)$ & .50 & & $0.09^{*}(0.03)$ & .21 \\
\hline \multicolumn{10}{|l|}{ level } \\
\hline $\begin{array}{l}\text { Time } 1 \text { home environment } \\
\text { quality }\end{array}$ & & $0.34^{*}(0.15)$ & .19 & & $0.04(0.05)$ & .07 & & $0.17^{*}(0.08)$ & .29 \\
\hline Maternal education (years) & & $0.47(0.27)$ & .17 & & $0.10(0.10)$ & .11 & & $0.04(0.11)$ & 0.04 \\
\hline \multicolumn{10}{|l|}{ Level 2} \\
\hline \multirow{3}{*}{$\begin{array}{l}\quad \text { Preschool quality } \\
\text { Moderation effects of preschool } \\
\text { quality }\end{array}$} & & $2.52(2.40)$ & .18 & & $0.84(0.67)$ & .18 & & $1.40^{*}(0.61)$ & .29 \\
\hline & $\chi^{2}$ & & & $\chi^{2}$ & & & $\chi^{2}$ & & \\
\hline & $16.75^{*}$ & & & 25.12 & & & $34.49^{*}$ & & \\
\hline \multirow{2}{*}{$\begin{array}{l}\text { Preschool quality X Time } 1 \text { home } \\
\text { environment quality }\end{array}$} & & $0.44^{*}(0.16)$ & $.42(+1 S D)$ & & $0.05(0.05)$ & & & $0.17^{*}(0.06)$ & $.82(+1 S D)$ \\
\hline & & & $-.03(-1 S D)$ & & & & & & $.32(-1 S D)$ \\
\hline
\end{tabular}

${ }^{*} p<.05$. 
deviation above the mean, home quality has a positive moderate effect on language and a strong positive effect on early literacy skills. When preschool classroom quality is one standard deviation below the mean, home quality becomes a trivial predictor of children's language and a moderate predictor of early literacy skills.

\section{Discussion}

In this study, we investigated associations between the quality of family environment and ECEC programs as they relate to preschoolers' language, communication, and early literacy outcomes. Intersections between the home environment and ECEC programs were our primary interest.

First, our initial hypothesis was not confirmed as we did not find associations between center-based toddler child care quality and child outcomes in the preschool years. Research on threshold effects in the classroom quality-child outcome association has suggested larger benefits for children's development when classroom quality is in the good to high range (Burchinal et al., 2009) and that high-quality classrooms may be necessary to improve children's developmental outcomes (Burchinal, Vandergrift, Pianta, \& Mashburn, 2010). Thus, it seems reasonable to hypothesize that our results could be due to the homogeneous low quality found among participating classrooms in this study. If empirically confirmed, this hypothesis would have important implications for Portuguese policy makers, professionals, and parents as center-based toddler child care in Portugal is considered to be of predominantly low-quality (Barros \& Aguiar, 2010; Pessanha et al., 2007).

Second, the quality of the home environment was positively associated with children's language and literacy outcomes in the preschool years. These results partially confirm our second hypothesis and are congruent with prior research findings (e.g., Bradley et al., 2011). They also expand on other developmental outcomes findings from a European study which reported similar results for intellectual and social development (Sylva et al., 2008). In addition, the home learning environment was found to be more predictive of children's developmental outcomes in the preschool years than maternal education, which Sylva et al. (2008) also suggested.

Third, the direct links of preschool quality to concurrent child outcomes showed a positive impact on children's early literacy skills, over and above the effect of home quality, as hypothesized. These results are consistent with previous findings (Burchinal et al., 2002; Howes et al., 2008; Mashburn, 2008), and complement research that has emphasized the implications of ECEC quality on children's cognitive and social outcomes (Burchinal, Campbell, Bryant, Wasik, \& Ramey, 1997; NICHD Early Child Care Research Network, 2000; Pierrehumbert, Ramstein, Karmaniola, le Miljkovitch, \& Halfon, 2002). Previous studies in Portuguese settings support such evidence, reporting associations between preschool global quality and children's early literacy skills, namely vocabulary, concepts about print, and phonological awareness (Abreu-Lima et al., 2012).

One of the most important studies to date, the NICHD Early Child Care Research Network study (1997, 1998a, 1998b, 2006), which compared the relevance of both the home environment and ECEC, reported consistent results for all the measured variables and indicated that ECEC quality explains less variance than do family variables. However, similar to recent findings (e.g., Pierrehumbert et al., 2002; Sylva et al., 2008), we found the effects of preschool quality were as strong as those of the home environment quality.

Fourth, our findings suggest that preschool quality may be an important moderator on the relationship between home environment quality and children's latter language and early literacy skills, even when also considering children's previous developmental level and maternal education. Our results show a synergetic positive effect of higher preschool quality on the associations between home environment quality and children's language and early literacy outcomes. These findings are complementary to prior studies that suggested a mediating effect of home environment quality on the associations between ECEC quality and children's outcomes (Lamb, 1998), and to previous results that suggested cumulative effects of home and preschool quality (NICHD, 1997, 1998a, 1998b, 2000, 2006). Findings reported here support the integrative model proposed by Howes (1999, as cited in Pierrehumbert et al., 2002) since they suggest cumulative effects of positive independent variables from two different educational contexts. Such cumulative positive effects on children's outcomes suggest that higher preschool quality potentiates the positive impact of home environment quality in predicting children's language and literacy outcomes. This evidence is stronger for early literacy skills, highlighting the relevance of promoting high quality in ECEC settings, as these skills are essential for developing proficient reading and writing skills as well as long-term academic success (Skibbe, Connor, Morrison, \& Jewkes, 2011). Likewise, several authors (e.g., Pianta, 2007) have identified early print knowledge as a relevant feature in high-quality preschool classrooms.

However, the moderating effects reported here add to previous knowledge on the intersections between home environment and ECEC quality. Our study further documents a detrimental effect of poor preschool quality, and suggests that low-quality ECEC may hinder or even nullify the positive effect of home environment quality on children's language and early literacy skills. In fact, Watamura et al. (2011) designated niches characterized by high-quality home environments and low-quality ECEC as lost resources. Our findings suggest that more can be at stake than low-quality ECEC programs' failure to potentiate the effects of high-quality home environments.

This study has limitations that should be acknowledged. First, both our research design and statistical analyses do not allow us to make cause-effect inferences. Second, three factors limit the external validity of our findings: the limited number of toddler and preschool child care classrooms included, the restricted geographical area from which these classrooms were recruited, and the specific quality features of these classrooms (which in the case of toddler child care, limit our findings to low-quality classrooms).

Despite these constraints, findings contribute to a better understanding of the associations between children's developmental outcomes and context quality in two of the child's main microsystems. In addition, this study provides an opportunity to examine the cross-cultural consistency of findings from quality studies conducted both in the U.S. and in Europe.

Keeping in mind the referred limitations, we cautiously trust that the effects found in this study may highlight possible communal effects. Carneiro and Heckman have argued that ECEC services are one of the few effective means of increasing economic opportunities for disadvantaged individuals and, therefore, for society as a whole (2002, as cited in NICHD Early Child Care Research Network, 2006). Presently, in Portugal, a large number of children spend extended periods of time in a variety of ECEC services - public, private, and clandestine - between birth and the time they enter school. For the first three years of children's lives, the quality of these services may range from inadequate to minimally adequate in terms of health, safety, and developmental appropriateness (Barros \& Aguiar, 2010; Pessanha et al., 2007). Although research results have shown that parental practices are a relevant predictor of child cognitive and social development outcomes due to genetic and environmental influences, highlighting the crucial importance of the family in children's lives (Collins, Maccoby, Steinberg, Hetherington, \& Bornstein, 2000), parents are not acting alone. When families decide to use ECEC services, they not only should feel that they are not harming their children, but they also have the right to know the characteristics of the contexts they 
choose and the possible effects of these environments on child development.

The need for more research on ECEC in Portugal is clear. Costbenefit analyses on the long-term effects of ECEC experiences are especially important, considering the high risk of poverty and the number of children involved in ECEC (Instituto Nacional de Estatística, 2010; Ministério da Educação, 2010). However, even well-established conclusions about ECEC effect sizes may not lead to policy changes. As Shonkoff (2000) claims, social scientists often emphasize data from this kind of research, but this is rarely considered in policy development. Assuming our share of coresponsibility in the prevention and solution of social problems, we hope that the knowledge gained from this study will be useful for parents, teachers, researchers, and politicians and contribute to bridging the gap between research and practice.

\section{Acknowledgements}

This study is part of two research projects titled respectively. The quality of child interactions in family and daycare settings and its influence on children's socio-cognitive development and Longitudinal Study of Children's Engagement and Adaptation developed by the Department of Psychology of the University of Porto and were supported by grants from the Foundation of Science and Technology (POCTI/PSI/35207/2000, POCI/PSI/58712/2004). These projects were coordinated by Professor Joaquim Bairrão to whom we address our appreciation and respect. The team is grateful for sharing his wisdom and knowledge.

The authors thank the teachers and directors of the centers that participated in the project along with the research team members, Ana José, Ana Susana Almeida, Carla Cid, Carla Peixoto Cristina Nunes, Fernando Santos, Helena Rosário, Leen Poppe, Margarida Guimarães, Maria da Paz Mascarenhas, Mónica Silva, Orlanda Cruz, Pedro Lopes dos Santos, and Sílvia Barros. The valuable comments and support of Margaret Burchinal, R.A. McWilliam, Joana Cadima, and Anne Kirby are also appreciated.

\section{References}

Abreu-Lima, I., Leal, T., Cadima, J., \& Gamelas, A. M. (2012). Predicting child outcomes from preschool quality in Portugal. European Journal of Psychology of Education, http://dx.doi.org/10.1007/s10212-012-0120-y

Aguiar, C., \& McWilliam, R. A. (2012). Consistency of toddler engagement across two settings. Early Childhood Research Quarterly, http://dx.doi.org/10.1016/j.ecresq.2012.04.003

Ahnert, L., \& Lamb, M. (2004). Child care and its impact on young children (2-5). In R. E. Tremblay, R. G. Barr, \& R. De V Peters (Eds.), Encyclopedia on early childhood development (pp. 1-6). Montreal, Quebec: Centre of Excellence for Early Childhood Development. Retrieved from: http://www.child-encyclopedia.com/pages/pdf/ahnert-lambangxp.pdf

Alves, R. A., Aguiar, C., Castro, S. L., \& Bairrão, J. (July 2004). Assessment of concepts about print using an ecologically valid task with Portuguese children. In Poster paper presented at the Eleventh Annual Meeting of the Society for the Scientific Study of Reading Amsterdam, Netherlands.

Anders, Y., Rossbach, H.-G., Weinert, S., Ebert, S., Kuger, S., Lehrl, S., et al. (2011). Home and preschool learning environments and their relations to the development of early literacy skills. Early Childhood Research Quarterly, 27, 231-244. http://dx.doi.org/10.1016/j.ecresq.2011.08.003

Área Metropolitana do Porto. (n.d.). Prioridades de desenvolvimento para 2007-2013 (Development priorities for 2007-2013). Retrieved from: http://www. amp.pt/fotos/gca/amp__prioridades_2007_a_2013_2_1190370053.pdf.

Bairrão, J., Barbosa, M., Borges, I., Cruz, O., \& Macedo-Pinto, I. (1990). Perfil nacional dos cuidados prestados às crianças com idade inferior a seis anos. (National profile of care to children under six years old). Lisbon, Portugal: Fundação Calouste Gulbenkian.

Bairrão, J., Leal, T., Abreu-Lima, I., \& Morgado, R. (1997). Educação pré-escolar [Preschool education]. In Ministério da Educação (Ed.), Estudos Temáticos. Vol. II: A Evolução do Sistema Educativo e o PRODEP (pp. 17-110). Lisbon, Portugal: Departamento de Avaliação, Prospectiva e Planeamento.

Baron, R. M., \& Kenny, D. A. (1986). The moderator-mediator variable distinction in social psychological research: Conceptual, strategic, and statistical considerations. Journal of Personality and Social Psychology, 51, 1173-1182.
Barros, S., \& Aguiar, C. (2010). Assessing the quality of Portuguese child care programs for toddlers. Early Childhood Research Quarterly, 25, 527-535. http://dx.doi.org/10.1016/j.ecresq.2009.12.003

Bradley, R. H., McKelvey, L. M., \& Whiteside-Mansell, L. (2011). Does the quality of stimulation and support in the home environment moderate the effect of early education programs? Child Development, 82, 2110-2122.

Burchinal, M. R., Campbell, F. A., Bryant, D. M., Wasik, B. H., \& Ramey, C. T. (1997) Early intervention and mediating processes in cognitive performance of children of low-income African American families. Child Development, 68, 935-954.

Burchinal, M. R., Kainz, K., Cai, K., Tout, K., Zaslow, M., Martinez-Beck, I., et al. (2009). Early care and education quality and child outcomes. Washington, DC: Office of Planning, Research and Evaluation, Administration for Children and Families, US DHHS, and Child Trends.

Burchinal, M. R., Peisner-Feinberg, E. S., Pianta, R., \& Howes, C. (2002). Development of academic skills from preschool through second grade: Family and classroom predictors of developmental trajectories. Journal of School Psychology, 40, 415-436.

Burchinal, M. R., Roberts, J. E., Nabors, L. A., \& Bryant, D. M. (1996). Quality of center child care and infant cognitive and language development. Child Development, $67,606-620$

Burchinal, M., Vandergrift, N., Pianta, R., \& Mashburn, A. (2010). Threshold analysis of association between child care quality and child outcomes for low-income children in pre-kindergarten programs. Early Childhood Research Quarterly, 25(2), 166-176. http://dx.doi.org/10.1016/j.ecresq.2009.10.004

Cadima, J., Leal, T., \& Burchinal, M. (2010). The quality of teacher-student interactions: Associations with first graders' academic and behavioral outcomes. Journal of School Psychology, 48, 457-482. http://dx.doi.org/10.1016/j.jsp. 2010.09.001

Caldwell, B. M., \& Bradley, R. H. (1997). Escala de Avaliação do Ambiente Familiar: Versão portuguesa (Home observation for the measurement of the environment: Portuguese version) (Universidade do Porto, Centro de Psicologia, Trans.). Centro de Psicologia, Universidade do Porto, Portugal (Original work published 1984).

Clay, M. M. (2003). Segue-me, lua: Adaptação portuguesa (Follow me, moon: Portuguese version) (R. Alves \& C. Aguiar, Trans.). Centro de Psicologia, Universidade do Porto, Portugal (Original work published 2000).

Cohen, J. (1988). Statistical power analysis for the behavioral sciences (2nd ed.). Hillsdale, NJ: Lawrence Erlbaum Associates.

Collins, W. A., Maccoby, E., Steinberg, L., Hetherington, E. M., \& Bornstein, M. (2000). Contemporary research on parenting: The case of nature and nurture. American Psychologist, 55, 218-232.

Conselho Nacional de Educação. (2011). Estado da Educação 2011. A Qualificação dos Portugueses [The state of education 2011. The qualifications of the Portuguese population]. Lisbon, Portugal: Author.

Cordazo, S. T., Almeida, A. M., \& Vieira, M. L. (2011). The influence of play in motor cognitive and social performance in school-age children. Educational Research 2(9), 1472-1480.

European Child Care and Education Study Group. (1997a). Questionário da família [Family Questionnaire] Centro de Psicologia, Universidade do Porto, Portugal.

European Child Care and Education Study Group. (1997b). Questionário de avaliação das características estruturais do jardim-de-infância e da creche [Preschool and daycare structural characteristics questionnaire - interview with the classroom teacher] Centro de Psicologia, Universidade do Porto, Portugal.

Gabinete de Estratégia e Planeamento. (2009). Carta Social - Folha informativa n ${ }^{\circ} 1$ [Social letter. informative paper no. 1]. Lisbon, Portugal: Ministério do Trabalho e da Solidariedade Social.

Griffiths, R. (1996). As Escalas Griffiths adaptadas ao Português: Versão parcial para investigação (The Griffiths Scales adapted to Portuguese: Partial version for research purposes) (S. L. Castro, \& I. Gomes, Trans.). Laboratório de Fala, Faculdade de Psicologia e de Ciências da Educação da Universidade do Porto, Portugal (Original work published 1984,1986$)$

Harms, T., Clifford, R., \& Cryer, D. (1998). Early childhood environment rating scale revised edition (ECERS-R). New York, NY: Teachers College Press.

Harms, T., Clifford, R., \& Cryer, D. (2008). Escala de Avaliação do Ambiente em Educação de Infância - Edição Revista (Early childhood environment rating scale - revised edition) (I. Abreu-Lima, C. Aguiar, A. M. Gamelas, T. Leal, \& A. I. Pinto, Trans.). Porto, Portugal: LivPsic/Legis Editora (Original work published 1998).

Harms, T., Cryer, D. \& Clifford, R. M. (1996). Escala de Avaliação do Ambiente de Creche (Infant/toddler environment rating scale - ITERS) (A. I. Pinto \& T. Grego, Trans.) Centro de Psicologia. Universidade do Porto, Portugal (Original work published 1990).

Howes, C., Burchinal, M., Pianta, R., Bryant, D., Early, D., Clifford, R. M., et al. (2008). Ready to learn? Children's pre-academic achievement in pre-kindergarten programs. Early Childhood Research Quarterly, 23, 27-50.

Instituto Nacional de Estatística. (2010). Sobre a pobreza as desigualdades e a privação material em Portugal [On poverty, inequality and material deprivation in Portugal]. Lisbon, Portugal: Author. Retrieved from: http://www.ine.pt/ xportal/xmain?xpid=INE\&xpgid=ine_publicacoes\&PUBLICACOESpub_boui= $100334100 \&$ PUBLICACOEStema $=55466 \&$ PUBLICACOESmodo $=2$

Kagan, J., Lapidus, D. R., \& Moore, M. (1978). Infant antecedents of cognitive functioning: A longitudinal study. Child Development, 49, 1005-1023.

Lamb, M. (1998). Nonparental child care: Context, quality, correlates, and consequences. In W. Damon (Series Ed.) \& I. E. Sigel, \& K. A. Renninger (Vol. Eds.) Handbook of child psychology: Vol. IV. Child psychology in practice (pp. 73-133) New York, NY: Wiley.

Mashburn, A. J. (2008). Quality of social and physical environments in preschools and children's development of academic, language, 
and literacy skills. Applied Developmental Science, 12(3), 113-127. http://dx.doi.org/10.1080/10888690802199392

Mashburn, A. J., Pianta, R. C., Hamre, B. K., Downer, J. T., Barbarin, O. A., Bryant, D. et al. (2008). Measures of classroom quality in prekindergarten and children' development of academic, language, and social skills. Child Development, 79(3), 732-749.

McWilliam, R. A., \& de Kruif, R. E. L. (1998). Engagement quality observation system III (E-Qual III). Chapel Hill, NC: Frank Porter Graham Child Development Center University of North Carolina at Chapel Hill.

Ministério da Educação. (2000). A educação pré-escolar e os cuidados para a infância em Portugal [Preschool education and early childhood care in Portugal]. Departamento de Educação Básica. Lisbon, Portugal: Author.

Ministério da Educação. (2009). Lei n. ${ }^{\circ}$ 85/2009 de 27 de Agosto [Law No. 85/2009 of Agosto 27]. Diário da República, 1.- série, N. .166 . Ministério da Educação.

Ministério da Educação. (2010). Perfil do aluno 2007/2008 [Student's profile 2007/2008]. Lisbon, Portugal: Gabinete de Estatística e Planeamento da Educação (GEPE). Retrieved from: http://www.gepe.min-edu.pt/np4/?newsId= 411\&fileName=GEPE_DSE_Perfil_Aluno_2007_08.pdf

Morrison, F. J., Gutman, L. M., Sameroff, A. J., \& Cole, R. (2003). Academic growth curve trajectories from 1st grade to 12th grade: Effects of multiple social risk factors and preschool child factors. Developmental Psychology, 39, 777-790.

National Institute on Child Health and Human Development Early Child Care Research Network. (1997). The effects of infant child care on infant-mother attachment security: Results of the NICHD study of early child care. Child Development, 68, 860-879.

National Institute on Child Health and Human Development Early Child Care Research Network. (1998a). Early child care and selfcontrol, compliance and problem behavior at 24 and 36 months. Child Development, 69, 1145-1170.

National Institute on Child Health and Human Development Early Child Care Research Network. (1998b). Relations between family predictors and child outcomes: Are they weaker for children in child care? Developmental Psychology, 34, 1119-1128.

National Institute on Child Health and Human Development Early Child Care Research Network. (2000). The relation of child care to cognitive and language development. Child Development, 71, 960-980.

National Institute on Child Health and Human Development Early Child Care Research Network. (2006). Child care effect sizes for the NICHD study of early child care and youth development. American Psychologist, 2, 99-116.

National Institute on Child Health and Human Development Early Child Care Research Network, \& Duncan, G. J. (2003). Modeling the impacts of child care quality on children's preschool cognitive development. Child Development, 74 , 1451-1475.

Organization for Economic Co-Operation and Development. (2007). Babies and bosses: Reconciling work and family life: A synthesis of findings for OECD countries. Paris, France: Author. http://dx.doi.org/10.1787/9789264032477-en

Organization for Economic Co-Operation and Development. (2008). Education at a glance 2009: OECD indicators. Paris, France: Author. Retrieved from: http://www.oecd.org/publishing/corrigenda

Peisner-Feinberg, E. S., \& Yazejian, N. (2010). Research on program quality: The evidence base. In P. W. Wesley, \& V. Buysse (Eds.), The quest for quality: Promising innovations for early childhood programs. Baltimore, MD: Paul H. Brookes Publishing.

Pereira, M., Soares, I., Dias, P., Silva, J., Marques, S., \& Baptista, J. (2010). Desenvolvimento, psicopatologia e apego: Estudo exploratório com crianças institucionalizadas e suas cuidadoras [Development, psychopathology and attachment: An exploratory study with institutionalized children and their caregivers]. Psicologia: Reflexão e Crítica, 23(2), 222-231.

Pessanha, M. (2008). Vulnerabilidade e resiliência no desenvolvimento dos indivíduos: Influência da qualidade dos contextos de socialização no desenvolvimento das crianças [Vulnerability and resilience in individuals's development: Influence of the quality of socialization contexts on children's development]. Lisbon, Portugal: Fundação Calouste Gulbenkian, Fundação para a Ciência e Tecnologia.

Pessanha, M., Aguiar, C., \& Bairrão, J. (2007). Influence of structural features on Portuguese toddler child care quality. Early Childhood Research Quarterly, 22(2), 204-214. http://dx.doi.org/10.1016/j.ecresq.2007.02.003
Pianta, R. C. (2007). Preschool is school, sometimes: Making early childhood education matter. Education Next, 7, 44-49.

Pierrehumbert, B., Ramstein, T., Karmaniola, A., Miljkovitch, R., \& Halfon, O. (2002). Quality of child care in the preschool years: A comparison of the influence of home care and day care characteristics on child outcome. International Journal of Behavioral Development, 26(5), 385-396.

Pinto, A. I. (2006). O envolvimento da criança em contexto de creche: Efeitos de características da criança, da qualidade do contexto e das interacções educativas. [Child engagement in child care: Effects of child characteristics, context quality, and teacher interactions on children's observed engagement] (Unpublished doctoral dissertation). Faculdade de Psicologia e de Ciências da Educação, Universidade do Porto, Portugal.

Pinto, A. I., Aguiar, C., Barros, S., \& Cruz, O. (2004). O Sistema de Avaliação da Qualidade do Envolvimento III: Um procedimento de avaliação do envolvimento da criança em contexto de creche [The engagement quality observation system III: A procedure for assessing child engagement in child care]. In C. Machado, L. S., Almeida, M. Gonçalves, \& V. Ramalho (Orgs.), Avaliação Psicológica: Formas e Contextos (Vol. X, pp. 441-448). Braga, Portugal: Psiquilíbrios Edições.

Raudenbush, S. W., \& Bryk, A. S. (2002). Hierarchical linear models: Applications and data analysis methods (2nd ed.). London, UK: Sage Publications.

Roberts, E., Bornstein, M. H., Slater, A. M., \& Barrett, J. (1999). Early cognitive development and parental education. Infant and Child Development, 8, 49-62.

Sammons, P., Sylva, K., Melhuish, E. C., Siraj-Blatchford, I., Taggart, B., \& Elliot, K. (2002). The effective provision of pre-school education (EPPE) project: Technical paper 8 a - measuring the impact of pre-school on children's cognitive progress over the pre-school period. London, UK: DfES/Institute of Education, University of London.

Sammons, P., Sylva, K., Melhuish, E. C., Siraj-Blatchford, I., Taggart, B., \& Elliot, K. (2003). The effective provision of pre-school education (EPPE) project: Technical paper $8 b$ - measuring the impact of pre-school on children's social/behavioural development over the pre-school period. London, UK: DfES/Institute of Education, University of London.

Shonkoff, J. P. (2000). Science, policy, and practice: Three cultures in search of a shared mission. Child Development, 71, 181-187.

Skibbe, L. E., Connor, C. M., Morrison, F. J., \& Jewkes, A. M. (2011). Schooling effects on preschoolers' self-regulation, early literacy, and language growth. Early Childhood Research Quarterly, 26, 42-49.

Sparrow, S. S., Balla, D. A., \& Cicchetti, D. V. 2000. (n.d.). Escala de Comportamento Adaptativo de Vineland (Vineland Adaptative Behavior Scales: Portuguese version for research purposes). (Universidade do Porto, Centro de Psicologia, Trans.). Portugal: Centro de Psicologia, Universidade do Porto (Original work published 1984).

Sylva, K., Melhuish, E., Sammons, P., Siraj-Blatchford, I., \& Taggart, B. (2008). Final report from the primary phase: Pre-school, school and family influences on children's development during key stage 2 (Age 7-11). London, UK: DfES/Institute of Education, University of London. Retrieved from: http://www.dcsf.gov.uk/research/

Sylva, K., Siraj-Blatchford, I., \& Taggart, B. (2003). Early childhood environment rating scale - extension (ECERS-E). Stoke on Trent, UK: Trentham Books.

United Nations Educational, Scientific, and Cultural Organization. (1982). Para uma política da educação em Portugal [For an education policy in Portugal]. Lisbon: Portugal: Livros Horizonte.

Vandell, D. L., Belsky, J., Burchinal, M., Steinberg, L., Vandergrift, N., \& NICHD Early Child Care Research Network. (2010). Do effects of early child care extend to age 15 years? Results from the NICHD study of early child care and youth development. Child Development, 81, 737-756. http://dx.doi.org/10.1111/j.1467-8624.2010.01431.x

Vasconcelos, T., Orey, I., Homem, L. F., \& Cabral, M. (2002). Educação de infância em Portugal: Situação e contextos numa perspectiva de promoção de equidade e combate à exclusão [Childhood education in Portugal: State of the art and contexts within an equity promoting approach and fight against exclusion]. Lisbon, Portugal: Conselho Nacional de Educação.

Watamura, S. E., Phillips, D. A., Morrissey, T. W., McCartney, K., \& Bub, K. (2011). Double jeopardy: Poorer social-emotional outcomes for children in the NICHD SECCYD experiencing home and child-care environments that confer risk. Child Development, 82, 48-65. http://dx.doi.org/10.1111/j.1467-8624.2010.01540.x 